\title{
Training plans, manager's characteristics and innovation in the accommodation industry
}

\author{
Ester Martínez-Ros ${ }^{a}$, Francina Orfila-Sintes ${ }^{b}, *$
}

a Universidad Carlos III, C/Madrid 126, 28903 Getafe, Madrid, Spain

b University of the Balearic Islands, Cra. Valldemosa, Km 7.5, 07122 Palma de Mallorca, Illes Balears, Spain

\section{A R T I C L E I N F O}

\section{Keywords:}

Innovation

Hotels

Training
A B S T R A C T

This paper explores the effect of training plans and managerial characteristics on innovation activity in the hospitality sector. This sector is featured by being labor-intensive so the examination of employment and managers skills deserves attention in order to determine the level of quality and competitive advantage in the provision of services. The data in the paper comes from a questionnaire administered to hotel managers in a representative sample of hotels in the Balearic Islands, a leading tourist destination. Results suggest that training plans positively affect innovation-related decisions and the extent of their implementation; however managers should have more than experience to manage the innovation change, specifically skills and capabilities.

\section{Introduction}

The service sector is now beginning to gain recognition as the core of the process of structural change in modern economies and is opening up new opportunities for aggregate growth and job creation. Nevertheless, the innovation, the human resources and its interaction should be properly managed to address these outcomes (Lopez-Cabrales et al., 2006; Zaccaro and Banks, 2004). Therefore, an accurate analysis of this sector may provide further information and a basis of knowledge for managerial as well as public policies that promote the introduction of new technologies through the human resources management in a sector traditionally considered residual. This paper specifically examines how training plans to improve employee skills and the role of managerial characteristics (skills and experience) enhance the probability and the intensity to innovate in the accommodation industry.

Previous studies have recognized the importance of human resources in innovation outcomes but nothing is said about the relation among employees training and innovation activities in the accommodation industry. This relation is relevant since the application of training plans in the hotels, allow them to update the formal education and reformulate resources and capabilities needed for getting innovation, competitiveness and hotel survival. This could be more important in the accommodation sector where the skill employment structure seems to be poorer than in other sectors.

\footnotetext{
Corresponding author. Tel.: +34 971171331; fax: +34 97117238

E-mail addresses: ester.martinez@uc3m.es (E. Martínez-Ros), francina.orfila@uib.es (F. Orfila-Sintes).
}

In line with the theory of innovation in services (Drejer, 2004; Gallouj and Weinstein, 1997; Sundbo, 1997) and empirical studies (Amable and Palombarini, 1998; Sirilli and Evangelista, 1998), this paper establishes a general framework for analyzing innovation in the accommodation sector when the main concern being the significant differences between different business sectors as to their innovation characteristics and results. On one hand, services have some special characteristics that should be considered when applying innovation theory which was first developed for manufacturing (Sundbo and Gallouj, 2000). On the other hand, service sectors also differ in the provision of service (Amable and Palombarini, 1998) since they require different skills, organize their production and marketing functions differently, make use of different levels of technology and serve different markets.

In this sense, tourism enterprises share service and particular tourism characteristics at the same time they are in heterogeneous sectors (Tremblay, 1998) in related aspects affecting innovation behavior. Among them, accommodation, which is a main tourism sector, is worthy of exploration.

This paper focuses the accommodations sector, thus the definition of innovation herein will refer specifically to improvements or changes that affect hotels. Furthermore, innovation requires changes in human resources to overcome the lack of skills. Leiponen (2005) recently emphasized the significance of employee skills in innovation and the lack of them as the single major obstacle to innovation in a wide range of industries and countries. Yet Pfeffer (1998) argued that innovation, speed and adaptability are largely derived from a company's human resources. Innovation's dependence on human capital may be even more important in the hotel industry, in which competitiveness largely depends on 
human resources (Furunes, 2005; Guerrier and Deery, 1998; Tsaur and Lin, 2004; Yeung, 2006). Hence, hotels should redouble their efforts to offer staff the opportunity to improve knowledge through training policies (Saks and Belcourt, 2006). Furthermore, in view of the particular characteristics of the hotel industry, employee skills (Furunes, 2005; Tsaur and Lin, 2004) and other important variables such as managerial attributes (Guerrier and Deery, 1998) are considered to explain the different levels of innovation between firms.

The empirical evidence provided by a representative sample of hotels in the Balearic Islands verifies the model about the hotels innovation. The Balearic Islands are a traditional mass tourism destination, which usually means the use of a price competition strategy that targets a large number of visitors to maintain prices and costs low. This strategy generates congestion problems and externalities in environmental and residential uses. Concern is growing about the need to change the patterns of a standardization strategy to a one based on high quality, innovation and the differentiation of a distinct level of service in a mature destination such as the Balearics, with its reliance on mass tourism. Organizations must introduce a number of innovations if they are to achieve this new objective (Aguiló et al., 2005).

In this article we provide evidence of some relevant human resource policies in promoting hotel innovation decisions that can foster its competitiveness. The use of training plans contributes to increase the innovation change in the hotel sector. This is coherent with international evidence (Saks and Belcourt, 2006; Furunes, 2005; for instance) that confers a relevant role to the human resources programs.

\section{Hotel innovation, training plans and managerial characteristics}

The changing environment that hotels face, force to them to look for ways of improving quality and reputation, efficiency and increasing market shares. One approach to improve competitive advantage is through innovation, or the ability to develop and launch new and successful hospitality services. The development of innovations has become a strategic driver to achieve competitiveness and productivity (Yeung, 2006). Specifically, innovation in best practice techniques is important in the sense that it is possible to change to a new consumer demand. Aguiló et al. (2005) have shown that stronger consumer demands, the growing importance of cultural factors, increasing wealth, new habits involving the use of communication and information technologies, a shift in the value placed on environmental resources and changes in families' socio-demographic and cultural characteristics, among others, have all led to the concept of a "new" consumer who requires a new type of tourism service. Mass tourism today has not only reached quantitative limits, but also it has reached qualitative ones as well: there has been a shift from mass package tourism to "post-Fordist" tourism. Post-Fordist tourists are independent, experienced and flexible tourists with more volatile preferences and a desire for "green tourism" or other alternative forms. Although Poon (1993) declared a clear rupture between the Fordist model of mass tourism (parallel to the Fordist model of the industrial age) and the current post-Fordist model of the post-industrial age, Aguiló et al. (2005) found a "new sun and sand tourist" whose demands are not so different from "old tourists". Thus, they found that classic sun and sand destinations are still competitive, mainly thanks to the efforts of the tourism industry and local government to restructure the market.

The considerable change in the structure of the Balearic tourism offer in recent years is an unmistakable sign of dynamism in this destination. Investments in hotels and the areas around them have improved quality. The initiatives taken by the Balearics respond to the changing patterns in origin markets and the destination has reoriented its offer towards a wider variety of better quality holiday products as a way to counter the trend towards stagnation and to achieve competitive tourism destinations and enterprises. Hotels are a representative set of homogeneous enterprises and a major part of the tourism industry. Furthermore, it is labor intensive and employee skills determine the quality of the output and competitive advantage (Furunes, 2005; Tsaur and Lin, 2004; Yeung, 2006).

To understand innovation in this sector, a framework in line with several studies based on independent surveys has been developed (Coombs and Miles, 2000; Djellal and Gallouj, 2000; Drejer, 2004; Gallouj and Weinstein, 1997; Sundbo, 1997, 2000; Sundbo and Gallouj, 2000). This framework focuses on particular service characteristics by developing context-specific concepts for service innovation practices. An ad hoc definition of innovation close to Schumpeter's is used in which innovation need not be radical and unpredictable to be considered true innovation. He acknowledged the importance of the cumulative nature of knowledge by stating that a technological revolution cannot be understood without reference to the development that led up to it. Moreover, he claims that it has become much easier to do things that lie outside the familiar routine, and that accordingly, innovation itself can be perceived as being reduced to routine, in the sense that technological progress has become the business of trained specialists (Schumpeter, 1942).

Incorporating technological assets into the provision process helps improve both productivity and services in the hospitality industry (Ngai and Wat, 2003). Therefore, innovation consists of technological incorporations into the key areas, departments and services that provide accommodation-related services (Hjalager, 2002): control processes (such as quality environmental management controls), computer equipment, information and telecommunications technologies, kitchens, food and beverage service, rooms, maintenance and savings in utilities, security, cleaning and laundry. Incorporating technologies developed in-house or those purchased from suppliers in these areas is apt to translate into a competitive advantage, thanks to either productive efficiency (decreased costs) or the capacity for differentiation (improving service by adapting it to consumer demand).

The different degrees of innovation between firms (Landau, 1991) are consequently analyzed by considering innovation as a function of a hotel's in-house resources: employees training and managerial characteristics.

Other employment skills also figure prominently in quality hospitality service, although their impact depends on the level of employee training (Ramos et al., 2004; Yeung, 2006). In reference to innovation, Damanpour (1996) argues that human resources and technology enable organizations to overcome obstacles to innovation, while Sirilli and Evangelista (1998) argue that training activities are one of the main channels to upgrading a firm's technological capabilities and lead to successful innovation. Training results in more highly skilled employees who will make better use of new technologies and be capable of providing better or new services (Lopez-Cabrales et al., 2006). Along the same lines, Leiponen (2005) indicates that hiring skilled employees may not be enough; employees also need to learn to use their skills within the organization. Indeed, the role of human resource skills seems to be more important in service innovation, as Preissl (2000) shows. She argues that knowledge enables people to handle rapidly changing technologies and endless flows of unstructured information and helps them select the relevant parts and turn them into meaningful production inputs.

A good employee training program provides a less formal, more flexible structural design and more highly skilled, motivated workers to achieve the final objective: to provide better services and 
achieve differentiation from rivals in a higher standardized competition. Several studies (e.g., Schneider and Bowen, 1985; Schneider et al., 1980, 1998; Wiley, 1996) highlight the existence of a connection effect between employees and customer satisfaction and affirm that implementing good managerial practices (effective advice and supervision, training programs, efficient, effective teams, for instance) are key factors in achieving high quality services and good results. Indeed, Zaccaro and Banks (2004) show the utility of training and development programs that target visioning and change management skills. Furthermore, Yeung (2006) found that training programs and enhanced mechanisms for information exchanges between players in the hotel sector provide a competitive advantage. In general, recent research suggests that training employees to do their jobs effectively is one of the most important tasks undertaken by managers to improve competitiveness (Saks and Belcourt, 2006). The relationship between innovation and upgrading human resources in the hotel industry is important because decisions related to innovation and company performance may hinge on human resource skills.

In the hotel industry, Pine (1992) shows that technology is more than just physical artifacts (machines and equipment): methods, processes, organizations and a strong human element are needed to take full advantage of technology in service industries, which are characterized as much by human interaction as by machines or equipment. Hotels need employees that are attitudinally as well as technically developed. Some areas of training are transfer indicators in service industries. The successful transfer of technology in the hotel industry depends upon the availability of employees who are being offered adequate education, training, development and promotional opportunities.

The "human touch" can also be added to services. This involves the need for highly qualified service providers who are able to offer a comprehensive, context-based interpretation and customization of random information, with all the different components of qualification required by innovation processes. One of the basic features and key competitive factors of hospitality services is the important role played by front-line staff: they determine the quality of output, given the closer provider-customer interaction. Since the hotel industry is a labor-intensive industry the way in which employees are qualified and trained will provide knowledge, ideas and creativity to the hotel and hence, increase the probability to introduce innovations. Te impact of employment skills on innovation depends on employee training (Yeung, 2006). Preissl (2000) argued that flexible adjustments as well as mechanisms and techniques to acquire new skills and qualifications are relevant variables in service innovations. Training enables employees to master new processes and offer a new type of service. These arguments lead to the following hypothesis:

H1. Training has a positive effect on innovation decision and on innovation intensity.

Nevertheless, each firm's training schedule may have different characteristics (Saks and Belcourt, 2006). Although training may promote innovation decisions, it is interesting to ascertain the different effects of each training types, as argued by Gavious and Rabinowitz (2003) and Wong and Pang (2003). Wong and Pang (2003) found training and development programs to be the most important factors in enhancing staff creativity. Similarly, Leiponen (2005) showed that internal interaction and feedback processes as well as those between the firm's internal and external sources of knowledge are the basis for successful innovation and lead to the need to combine different kinds of knowledge in the innovation process, i.e., external and internal sources of knowledge complement each other in the innovation process. As for other training features, Pine (1992) indicated that formal and informal education (garnered through on-the-job experience) holds the key to achiev- ing the individual attitudinal and technical development required. In this sense, the characteristics of the different training that can be distinguished lead to the following hypothesis:

H2. When the training is constant and internal the effect on innovation decision and intensity is positive and higher than when the training are occasional and external.

The role of managers in promoting innovation has been debated in literature on the subject (e.g., Saks and Belcourt, 2006). Damanpour (1996) suggested that managerial attitudes to change may affect innovation-related decisions and Heine et al. (2003) showed that individual roles and management processes heavily influence technological outcomes. Management issues are also important in innovation and services (Preissl, 2000). Guerrier and Deery (1998) point out that one of a hospitality unit manager's strategic skills is managing quality and handling risk and uncertainty and that a manager's individual attributes are crucial to successful organizations. They also highlighted managerial attitudes as key determinants in innovation, development and acquisition. Winata and Mia (2005) asserted that managers in the hotel industry face increasingly uncertain and complex work environments because of the industry's unique service characteristics. They may be considered as one of the main "core employees" that contributes to the activity of the firm and whose skills and abilities determine organizational differences in capabilities and efficiency when performing the organization's base operations (Lopez-Cabrales et al., 2006). That is, the managers can face changing turbulent environments adapting internal structures and processes quickly through new streams of knowledge and changing their routines to filling actual and potential needs of customers. Therefore, the managers possess the proper set of behaviors for making improvements in current operations such as innovations. In other words, Zaccaro and Banks (2004) argue that managers at all organizational levels need to have strong skills or managerial competences in managing change.

Another important characteristic is how productive units are operated. The hotel business management of each productive unit may be run by the owner of the property or another entity contracted by the owner to handle management, which involves different incentives and risks (Getz and Carlsen, 2005). Ownership structure and the degree of dependence on other organizational structures influence the framework of managerial decisions about innovation. As Sirilli and Evangelista (1998) suggest, the different ways production unit structures are organized may affect innovative behavior. Furthermore, the manner in which hotel establishment is run determines managerial competences. Hence, ownership is another important facet to be taken into consideration when studying managers. Lynch and MacWhannell (2000) agree that entrepreneurship in hospitality research has received relatively little attention and recognize a need to delve deeper into the effects of ownership on the introduction of innovation in all areas, because of the large proportion of family-owned and operated tourism firms in the sector. Getz and Carlsen (2005) found that owner-operated firms have more entrepreneurial attitudes, because they control and monitor the entire decision-making process.

All the above leads to the conclusion that managing innovation requires a great deal of experience, knowledge and training if maximum performance is to be achieved. Knowledge about innovation can come from work experience in (on-going learning). Developing skills "that cannot be taught" is an important element in the innovation process. Practical experience within the same firm or a similar post in another firm, at the least, is a rarely found and highly appreciated managerial skill. Thus, two aspects of hotel managers may play an important role in the decisions about innovation they make: experience and qualifications. Experience may influence 
innovation-related decisions because it represents the skills and abilities managers have at their disposal when translating knowledge into change. Qualifications represent the knowledge resources managers have available when implementing innovations. These arguments lead to the formulation of the following hypothesis:

H3. A more educated manager's with higher expertise and owner of the hotel will increase the probability and the intensity to innovate.

\section{Materials and methods}

\subsection{Data sources}

The empirical analysis focuses on hotel establishments in the Balearic Islands since the majority of all tourists, $62 \%$, choose to stay in hotels, instead of other possible alternatives such as tourism apartments (Instituto de Estudios Turísticos, 2003). The universe for this study is made up of all hotel establishments in the Balearic Islands: 1586 establishments (according to the official census for 2000 compiled by companies in the tourism sector and released by the local Tourism Council), since establishments in the "Other" category were excluded, as they represent a mere $0.5 \%$ of the total beds in the universe. The "Other" category was also dropped because its items operate more heterogeneously and offer a wider range of services and therefore are not directly comparable to the other categories in the universe, made up of guesthouses, boarding houses, residences, apart-hotels and hotels.

Public databases - aggregate data on R\&D, patents, and so on are neither suitable for quantifying innovation in the hotel trade, which does not allocate significant resources for generating new knowledge on innovation, nor typically gives rise to the registration of patents (Hjalager, 2002). Thus, information on innovation in the field must be extracted from primary information sources, i.e., hotel establishments. Therefore, the set of relevant data has been extracted from a questionnaire specifically devised for hotel managers.

A representative sample from the universe was selected after stratification according to three characteristics that make it heterogeneous: geographical location (three islands in the Balearic archipelago), category and available bed capacity. The 331 elements in the sample were proportionately and randomly selected from among the layers yielded by the classification of the universe, was representative and led to a confidence level of $95.5 \%$ in the results. The sample selection process was complemented by a controlled substitution process for inaccessible hotels; each inaccessible hotel was replaced by another in the same layer to maintain stratification unaltered and obtain the desired 331 observations (i.e., an average response level of $100 \%$ ).

A questionnaire was specifically designed and administered to hotel managers in personal interviews conducted by specially trained interviewers to obtain the relevant data on the levels and types of innovation and related variables. A preliminary version of the questionnaire was applied during the summer of 2001 . The results were exploited and several relevant questions about training plans and hotel managers were added for three further applications of the questionnaire to the same sample during the summers of 2004, 2007 and 2010. This study uses the data from these three applications.

\subsection{Variables}

\subsubsection{Dependent variables}

Innovation decisions in each hotel establishment were defined as innovative activities carried out during the preceding three years in key functional hotel areas, departments or services (i.e., con- trol processes, computer equipment, etc.). The managers rated each area on the basis of the examples provided by interviewers in one of the four following categories: One, no change. Two, first time innovated. Third, improved, expanded or renovated area. Four, the activity concerned is being outsourced or provided by the company's central services.

The binary variable Innovation Decision measures existing innovation and equals one when at least one area was ranked in categories two or three and equals zero in other cases. Therefore, the value of one corresponds to establishments with innovation in at least one or in all areas. The categorical variable Innovation Intensity measures the number of areas each establishment innovated to obtain data on the degree of innovation. The different areas of innovation in the questionnaire were divided into the following five groups: One, quality management, including environmental quality management, room installations and organizational structure (departments or work teams). Two, information technology equipment (computer equipment and hardware). Three, information and communication technologies applied for external relationships (tourists, other businesses and public administrations) and information. Four, information and communication technologies applied in internal operations and information management. Five, complementary operations (kitchen equipment, dining rooms, bars, restaurants, security, cleaning, laundry and maintenance). The categorical variable Innovation Intensity counts the number of areas ranked as innovated and ranges from zero to five.

\subsubsection{Explanatory variables}

Training activities in hotel establishments such as flexible adjustments and mechanisms and techniques for acquiring new skills and qualifications are measured by the binary variable Training, which roughly represents an existing employee training plan in a hotel when it equals one. The following binary variables contribute more detail on the frequency and source of training plans. The variable Constant Training equals one when the training plan is on-going and equals zero otherwise. The variable Occasional Training equals one when the training plan consists of sporadic training activities. The variable Internal Training equals one when training activities are organized by the hotel establishment or company and equals zero otherwise. The variable External Training equals one when training activities are organized by another firm or organization.

Experience and qualifications are skills and attributes that may influence hotel managers when making decisions to innovate. The variable Experience approximates experience in a similar post, a rarely found and highly valued management skill. Experience is measured by the years a hotel manager has been working in the industry, including the current establishment. The binary variable Education approximates hotel managers' knowledge resources by capturing their level of education. The variable Education equals one when a hotel manager has an intermediate or advanced degree and equals zero in other cases. The variable Owner equals one when hotel is owner-operated and equals zero when the management is run by a separate entity hired by the ownership for this purpose (e.g., leasing a building or a management contract with a hotel firm).

Control Variables. The categorical variable Category measures the quality level tourists expect according to a hotel's number of stars, which are awarded by the Tourist Administration according to legal requirements and technical specifications. Nevertheless the five legal categories have been aggregated into four, with four and fivestar establishments grouped into one category. Establishments in the top category (five stars) account for no more than $1 \%$ of overall capacity and only differ very slightly from four-star establishments.

The intensity in use of knowledge and information resources assets is measured by the variable Months, which equals the number of months a year a hotel establishment remains open. 
Organization in hotel chains with a main office which have different attributions and several degrees of vertical integration according to the company involved is measured by the variable NoChain. This variable equals one if the hotel operates in the market as an independent establishment and equals zero if it operates in the market as a part of a chain.

The binary variables Year2004 and Year2007 equal one when the year is 2004 and 2007.

\subsection{Research methods}

The research methods consists of econometric estimations that ascertain whether training plans and hotel managers' attributes determine innovation decisions and the extent of innovation in hotels. In other words, the results indicate whether the explanatory variables significantly influence the expected probability for the hotel establishments to innovate and whether this influence is positive or negative. Furthermore, the marginal effects of these econometric estimations approximate the degree in which the expected probability of the innovation decision will increase (reduce) when the value of the explanatory variable changes from its mean value.

The innovation decision represented by the binary variable Innovation Decision must be estimated with discrete choice models, such as Probit model, that properly fit the binary option of the dependent variable. The degree of innovation activity represented by the variable Innovation Intensity must be estimated with discrete choice models that properly fit the count characteristic of the dependent variable: a Poisson model. The comparison between these models marginal effects reinforces the interpretation of results pertaining to the validation of the hypotheses on the factors that promote innovation in the accommodations sector. Moreover, the comparison analyses whether the explanatory factors in innovation differ in terms of degree.

Since we have three cross-sections, we generate results for these three waves and for the pool data. With these diverse results we could test the hypotheses and also in these evolution taking into account the economic cycle and the possible external effects that could affect the innovation decision and the innovation intensity.

\section{Results}

On average the hotel manager in the Balearic Islands is a man (71\%) who is nearly forty-six years old, has been working in the accommodations sector for almost twenty one years and has an intermediate or advanced degree (89\%). Most of firms (82\%) in the Balearic hotel industry have training plans, $42 \%$ of which are constant and $40 \%$ occasional. Internal training activities (58\%) and externally organized courses (49\%) also present a similar average frequency. The sum of internal and external training, 107\%, exceeds the total training plan since they may appear simultaneously (Table 1).

Tables $2 \mathrm{a}$ and $2 \mathrm{~b}$ displays the Probit and Poisson models marginal effects for pool data and for 2004, 2007 and 2010 that contribute quantitative information about the increase or reduction that the corresponding explanatory variable will cause in the probability of the establishment's innovation decisions in the pool and in each year. In Poisson estimations, the marginal effects represent the changes of explanatory variables in the intensity of innovation activity represented by the number of areas that the hotel introduces some innovation, like new TICS in the rooms or environmental improvements, for instance.

These two models were estimated for training and training characteristics, because the former is a linear combination

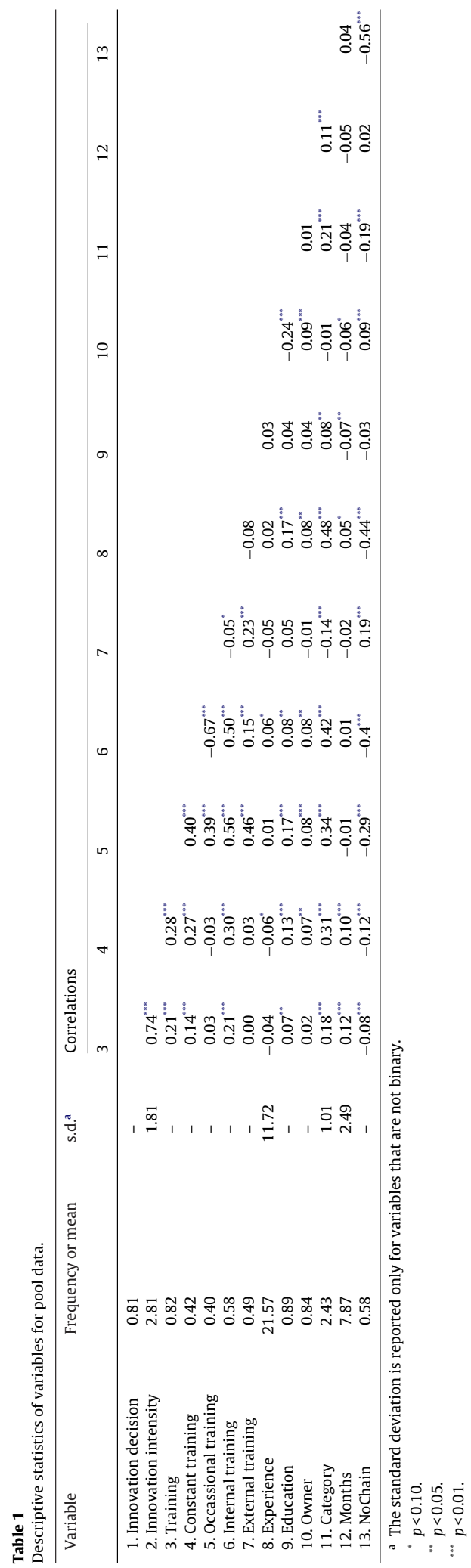


Marginal effects of innovation decision and innovation intersity for pool data.

\begin{tabular}{|c|c|c|c|c|c|c|}
\hline \multirow[t]{2}{*}{ Hypotheses } & \multicolumn{6}{|c|}{ Innovation decision $^{\mathrm{a}}$} \\
\hline & Controls & $\mathrm{H} 1$ & $\mathrm{H} 2$ & $\mathrm{H} 3$ & $\mathrm{H} 1$ and $\mathrm{H} 3$ & $\mathrm{H} 2$ and $\mathrm{H} 3$ \\
\hline \multicolumn{7}{|l|}{ Control variables } \\
\hline Category & $0.077^{* * *}$ & $0.061^{* * *}$ & $0.047^{* * *}$ & $0.076^{* * *}$ & $0.060^{* * *}$ & $0.046^{* * *}$ \\
\hline Months & $0.016^{* * *}$ & $0.016^{* * *}$ & $0.014^{* * *}$ & $0.020^{* * *}$ & $0.019^{* * *}$ & $0.016^{* * *}$ \\
\hline NoChain & 0.003 & 0.026 & 0.049 & -0.006 & 0.020 & 0.044 \\
\hline Year2004 & $0.147^{* * *}$ & $0.157^{* * *}$ & $0.158^{* * *}$ & $0.163^{* * z}$ & $0.172^{* * *}$ & $0.174^{* * *}$ \\
\hline Year2007 & $0.160^{* * *}$ & $0.158^{* * *}$ & $0.159^{* * *}$ & $0.121^{* * *}$ & $0.111^{* * *}$ & $0.115^{* * *}$ \\
\hline Training & & $0.182^{* * *}$ & & & $0.205^{* * *}$ & \\
\hline \multicolumn{7}{|l|}{ Training characteristics } \\
\hline Constant training & & & $0.176^{* * *}$ & & & $0.173^{* * *}$ \\
\hline Occasional training & & & $0.153^{* * *}$ & & & $0.155^{* * *}$ \\
\hline Internal training & & & $0.061^{*}$ & & & $0.079^{* *}$ \\
\hline External training & & & $-0.076^{* *}$ & & & $-0.059^{*}$ \\
\hline \multicolumn{7}{|l|}{ Manager characteristics } \\
\hline Experience & & & & -0.001 & -0.001 & -0.001 \\
\hline Education & & & & $0.079^{*}$ & 0.058 & 0.052 \\
\hline Owner & & & & 0.048 & 0.043 & 0.045 \\
\hline \multicolumn{7}{|l|}{ Estimation values } \\
\hline Observations $^{\mathrm{b}}$ & 993 & 993 & 993 & 861 & 861 & 861 \\
\hline LR chi2(f.d.) & 95.70 & 122.50 & 139.40 & 86.05 & 112.30 & 126.00 \\
\hline Prob $>$ chi 2 & 0.000 & 0.000 & 0.000 & 0.000 & 0.000 & 0.000 \\
\hline Pseudo R2 & 0.100 & 0.127 & 0.145 & 0.100 & 0.130 & 0.146 \\
\hline$\%$ of correct predictions & 80.74 & 82.24 & 81.74 & 79.93 & 80.39 & 80.97 \\
\hline \multirow[t]{2}{*}{ Hypotheses } & \multicolumn{6}{|c|}{ Innovation intensity ${ }^{c}$} \\
\hline & Controls & $\mathrm{H} 1$ & $\mathrm{H} 2$ & $\mathrm{H} 3$ & $\mathrm{H} 1$ and $\mathrm{H} 3$ & $\mathrm{H} 2$ and $\mathrm{H} 3$ \\
\hline \multicolumn{7}{|l|}{ Control variables } \\
\hline Category & $0.616^{* * *}$ & $0.497^{* * *}$ & $0.404^{* * *}$ & $0.562^{* * *}$ & $0.455^{* * *}$ & $0.346^{* * *}$ \\
\hline Months & $0.045^{* *}$ & $0.048^{* *}$ & $0.041^{* *}$ & $0.070^{* * *}$ & $0.062^{* * *}$ & $0.054^{* *}$ \\
\hline NoChain & 0.169 & $0.266^{* *}$ & $0.390^{* * *}$ & 0.153 & $0.265^{* *}$ & $0.390^{* * *}$ \\
\hline Year2004 & $0.877^{* * *}$ & $0.930^{* * *}$ & $0.989^{* * *}$ & $0.855^{* * *}$ & $0.872^{* * *}$ & $0.934^{* * *}$ \\
\hline Year2007 & $0.950^{* * *}$ & $0.934^{* * *}$ & $0.972^{* * *}$ & $0.632^{* * *}$ & $0.555^{* * *}$ & $0.612^{* * *}$ \\
\hline Training & & $1.100^{* * *}$ & & & $1.194^{* * *}$ & \\
\hline \multicolumn{7}{|l|}{ Training characteristics } \\
\hline Constant training & & & $1.521^{* * *}$ & & & $1.562^{* * *}$ \\
\hline Occasional training & & & $1.116^{* * *}$ & & & $1.135^{* * *}$ \\
\hline Internal training & & & $0.282^{*}$ & & & $0.361^{* *}$ \\
\hline External training & & & $-0.229^{*}$ & & & -0.159 \\
\hline \multicolumn{7}{|l|}{ Manager characteristics } \\
\hline Experience & & & & -0.006 & -0.007 & $-0.010^{*}$ \\
\hline Education & & & & $0.591^{* * *}$ & $0.432^{* *}$ & $0.444^{* *}$ \\
\hline Owner & & & & $0.371^{* * *}$ & $0.304^{* *}$ & $0.273^{*}$ \\
\hline \multicolumn{7}{|l|}{ Estimation values } \\
\hline Observations ${ }^{\mathrm{b}}$ & 993 & 993 & 993 & 861 & 861 & 861 \\
\hline LR chi2(f.d.) & 178.30 & 240.50 & 268.70 & 169.30 & 230.30 & 256.30 \\
\hline Prob $>$ chi 2 & 0.000 & 0.000 & 0.000 & 0.000 & 0.000 & 0.000 \\
\hline Pseudo R2 & 0.043 & 0.058 & 0.065 & 0.047 & 0.064 & 0.072 \\
\hline$\%$ of correct predictions & 35.76 & 37.26 & 38.16 & 29.82 & 31.82 & 34.57 \\
\hline $\begin{array}{l}\text { a Probit models. } \\
\text { b Observations in the estin } \\
\text { c Poisson models. } \\
\text { * } p<0.10 . \\
\text { * } p<0.05 . \\
p<0.01 .\end{array}$ & s than 331 & e missing & variables. & & & \\
\hline
\end{tabular}

of the latter and the inclusion of both makes it impossible to estimate the model. A negative binomial estimation was also calculated for the variable Innovation Intensity and is not shown, since the results are identical to the Poisson results. The estimated models are useful in explaining hotels' innovation decisions and degree of intensity, since the overall effect of the explanatory variables on the dependent variable is statistically significant in all cases. Results are robust for both equations estimated.

Findings for training programs clearly support $\mathrm{H} 1$ and $\mathrm{H} 2$. For firm the inclusion a plan for training results in significant and positive effect on innovation decision. The effect is even greater when the degree of innovation is taken into account. When we distinguish between different plans of training, we observe what we expected, that is firms prefer constant and internal training than occasional and external.

With respect to education, we found that a more highly skilled manager produce higher intensity innovation but do not influence on the innovation decision. Higher skill managers enhance to hotels the introduction of innovation in more areas.

We found that managerial experience had a negative effect on both innovation decision-making and degree. However, a significant, positive effect can be seen for ownership in the degree of innovation. It is not possible to be conclusive about $\mathrm{H} 3$ because of the mixed effect observed. The negative effect of managerial experience is surprising and indicates that managers are more confident about their own skills and capacities than in innovations, yet owner-managers are more convinced about introducing 
Table 2b

Marginal effects of innovation decision and innovation intensity for 2004, 2007 and 2010.

\begin{tabular}{|c|c|c|c|c|c|c|c|c|c|c|c|c|}
\hline \multirow[t]{2}{*}{ Hypotheses } & \multicolumn{4}{|l|}{2004} & \multicolumn{4}{|l|}{2007} & \multicolumn{4}{|l|}{2010} \\
\hline & \multicolumn{2}{|c|}{ Innovation decision $^{\mathrm{a}}$} & \multicolumn{2}{|c|}{ Innovation intensity ${ }^{\mathrm{b}}$} & \multicolumn{2}{|c|}{ Innovation decision $^{\mathrm{a}}$} & \multicolumn{2}{|c|}{ Innovation intensity ${ }^{\mathrm{b}}$} & \multicolumn{2}{|c|}{ Innovation decision $^{\mathrm{a}}$} & \multicolumn{2}{|c|}{ Innovation intensity ${ }^{\mathrm{b}}$} \\
\hline \multicolumn{13}{|l|}{ Control variables } \\
\hline Category & $0.080^{* * *}$ & $0.061^{* * *}$ & $0.633^{* * *}$ & $0.512^{* * *}$ & $0.059^{* *}$ & $0.040^{+}$ & $0.542^{* * *}$ & $0.446^{* s z}$ & 0.038 & 0.014 & $0.270^{* * *}$ & 0.094 \\
\hline Months & $0.019^{* * * * *}$ & $0.015^{* *}$ & $0.079^{* *}$ & $0.071^{*}$ & $0.023^{* * *}$ & $0.021^{* z}$ & $0.083^{*}$ & $0.086^{*}$ & 0.007 & 0.005 & 0.029 & 0.016 \\
\hline NoChain & 0.033 & $0.088^{+}$ & 0.228 & $0.449^{* *}$ & -0.044 & -0.014 & 0.029 & 0.274 & 0.058 & 0.053 & $0.527^{* * *}$ & $0.485^{* *}$ \\
\hline Training & $0.084^{* *}$ & & $1.175^{* * *}$ & & $0.282^{2 * *}$ & & $1.546^{* * *}$ & & $0.265^{* s *}$ & & $1.165^{* * *}$ & \\
\hline \multicolumn{13}{|l|}{ Training characteristics } \\
\hline Constant training & & 0.095 & & $1.487^{* * *}$ & & $0.261^{* * *}$ & & $2.585^{* * *}$ & & $0.215^{* *}$ & & $1.315^{* *+}$ \\
\hline Occasional training & & 0.012 & & $0.878^{* *}$ & & $0.190^{* s}$ & & $1.862^{s s z}$ & & $0.269^{* * *}$ & & $1.200^{* * * *}$ \\
\hline Internal training & & $0.093^{+}$ & & $0.419^{+}$ & & 0.011 & & 0.178 & & $0.141^{*}$ & & $0.618^{* *+*}$ \\
\hline External training & & 0.033 & & -0.053 & & -0.040 & & -0.104 & & $-0.147^{* *}$ & & $-0.514^{* *+1}$ \\
\hline \multicolumn{13}{|l|}{ Manager characteristics } \\
\hline Experience & $-0.002^{+}$ & $-0.002^{+}$ & -0.002 & -0.001 & 0.002 & 0.001 & -0.001 & -0.006 & -0.003 & $-0.003^{+}$ & $-0.017^{* *}$ & $-0.018^{* *}$ \\
\hline Education & -0.014 & -0.002 & 0.272 & $0.399^{+}$ & $0.132^{+}$ & 0.106 & 0.323 & 0.237 & 0.114 & 0.056 & $0.751^{* *}$ & $0.587^{*}$ \\
\hline Owner & 0.011 & -0.008 & $0.325^{+}$ & 0.192 & -0.041 & -0.045 & -0.223 & -0.344 & $0.181^{s *}$ & $0.236^{* *}$ & $0.962^{* * *}$ & $1.039^{* *+*}$ \\
\hline \multicolumn{13}{|l|}{ Estimation values } \\
\hline Observations ${ }^{c}$ & 320 & 320 & 320 & 320 & 227 & 227 & 227 & 227 & 314 & 314 & 314 & 314 \\
\hline LR chi2(f.d.) & 38.36 & 49.04 & 99.38 & 114.47 & 44.41 & 47.60 & 63.16 & 69.53 & 21.82 & 37.32 & 64.42 & 88.88 \\
\hline Prob $>$ chi2 & 0.000 & 0.000 & 0.000 & 0.000 & 0.000 & 0.000 & 0.000 & 0.000 & 0.000 & 0.000 & 0.000 & 0.000 \\
\hline Pseudo R2 & 0.15 & 0.196 & 0.077 & 0.091 & 0.224 & 0.240 & 0.0699 & 0.0770 & 0.0580 & 0.0992 & 0.0477 & 0.0658 \\
\hline$\%$ of correct predictions & 86.56 & 86.62 & 27.81 & 33.76 & 85.02 & 85.46 & 25.68 & 26.78 & 72.29 & 72.93 & 23.84 & 25.34 \\
\hline
\end{tabular}

a Probit models.

b Poisson models.

c Observations in the estimations are less than 331 due to some missing values in the variables.

${ }^{*} p<0.10$.

$p<0.05$

$p<0.01$

$+p<0.20$. 
innovations in several areas of hotels. In the estimations, we have taken into account the experience of manager in the same hotel and the higher education versus non-skilled.

Finally, the inclusion of three waves of the data has allowed us to control for the economic cycle. Findings show the evolution of main variables considered in our analysis and how they change along the period. Clearly, hotels realize in 2010 the importance of training plans and the upgrade of manager to overcome the drawbacks stemmed from a severe economic and financial crisis that developed countries have experienced.

\section{Conclusions}

\subsection{Discussion}

An analysis of the relationship between innovation and employment skills in the service industry is highly recommended, given the theoretical and empirical development of innovation in this important sector of modern economies. Nevertheless, because of the specificity of innovation in different services, this study focuses on one of the most prominent tourism sectors, the hotel industry. In this sector employment skills are key determinants in the quality of service, which marks a competitive advantage. This study establishes a general framework for analyzing innovation in the accommodation sector considering its intra-sectoral differences and develops an specific innovation measure in the light of the relevant previous literature. The empirical verification of the model with data from a world leading tourism destination allow relevant conclusions about the main drivers considered: training and managers' characteristics.

Along with other studies, this study found that using training programs helps improve a firm's competitive edge. Moreover, we also provide evidence that training plans are not only important in the innovation decision but also in its intensity. Clearly, when firm introduce this type of best human practice the probability to develop more innovation increase a lot.

Our results suggest some useful insights related to training. Specifically, evidence can be seen of the positive relationship between employee training plans and the probability of introducing innovations in hotels to offer better services. It is important to note that the positive impact of training activities on innovation differs according to training characteristics and to the innovation types under consideration. Only internal training plays role in the innovation decision while continuous and sporadic plans are relevant in the innovation carry out intensity. It suggest that strong employment commitment through training confers positive influences in innovation activity. Specifically, it is worth noting the positive effect of internal training versus the negative sign of external training. This significant difference could indicate how firms consider the necessity to transform the knowledge and skills of employees in a more concrete way taking into account that this sector is demanding of a good service traduced in a "human touch" and a "higher customization". These specific abilities of employees are expected to provide gains in competitiveness. On the other hand, we find similar effect of the constant training and the occasional training. This inform us no matter the form of training is conducted, the important is the inclusion of this type of human resources policy in the firm strategy to achieve productivity and competitiveness. This finding is also reported in the literature (Leiponen, 2005).

The negative impact of managerial experience in the current establishment and hotel industry may suggest that managers confide strongly in their own abilities and are somewhat reluctant to assume the risks associated with innovation. Furthermore, an agency-relationship effect may exist (Galende, 2006): hotel managers investing in innovation must report a certain expense that will be profitable in the future when they may be working in another establishment or firm. More experienced directors may possibly consider this a deterrent. However, while managerial skills affect neither decisions nor intensity of innovation, the owner effect fosters innovation in many areas.

An interesting result is the positive effect of the identification of owner and manager on innovation because it shows the relevant impact of incentives in a crisis context. The owner prefer to manage the hotel when the situation is not adequate because is a better form to control the internal activity. In terms of education, we find a significant positive effect in the innovation intensity for 2010. As before, we could interpret this result as the necessity to absorb the knowledge from education in the crisis periods. The cost of those skills and knowledge are more understandable when they are more necessaries for the hotels.

A prior conclusion to be drawn consists in the usefulness of the industry in-depth analysis of the every sector providing tourism services before undertaking complex interactions between them to conform tourism innovation. In this sense, the specific hotels innovation measurement seems to properly fit the hotel industry features although more in-depth studies could contribute with significant improvements. In a more services and tourism focus, another main conclusion is the importance to consider the employment skills in these labor intensive sectors in which these skills are key determinants of the competitive advantage. Innovation activity is supported by the use of some human practices as training and should take into account the managers characteristics to convince them the necessity to introduce innovations to improve quality in the provision of service.

\subsection{Managerial implications}

Moreover, some managerial implications can be drawn as the importance of the employees training and the managers characteristics. Economic and financial crisis have lead to companies, and hotels, to confer education and training a key role to overcome the consequences, like competitive advantage from rivals or even firm survival.

A second idea is reinforced that hotels with managers and owners in the same person have more incentives to innovate. The reason could be that the owner receives all the inversion with all security while other management forms that are optimal in other dimensions prevent this innovation inversion recuperation. Consequently, managers that are not owners could consider their lower incentives when deciding about innovation.

In any case, these results are useful as an orientation to address hotels and others sectors innovation and to support managerial decisions oriented to competitiveness.

\subsection{Limitations and further research}

Nevertheless, the analysis has some limitations. The first limitation is considering hotels in a unique zone, hence the general inference of hotels behavior is limited until the analysis be reproduced in other tourist destinations and in another time periods to have more data to enrich comparisons and general conclusions without geographical and time limitations. Another drawback is all the other managers' characteristics affecting innovation such as attitudes, decision-making, personality.

\section{Acknowledgements}

Francina Orfila-Sintes acknowledges financial support provided by the Spanish Ministry of Education and Science, through the SEJ2007-67895-C04-03/ECON project. 


\section{References}

Aguiló, E., Alegre, J., Sard, M., 2005. The persistence of the sun and sand tourism model. Tourism Management 26, 219-231.

Amable, B., Palombarini, S., 1998. Technical change and incorporated R\&D in the service sector. Research Policy 27, 655-675.

Coombs, R., Miles, I., 2000. Innovation, measurement and services: the new problematique. In: Metcalfe, J., Miles, I. (Eds.), Innovation Systems in the Service Economy. Kluwer Academic Press, London, pp. 85-124.

Damanpour, F., 1996. Organizational complexity and innovation: developing and testing multiple contingency models. Management Science 42, 693-716.

Djellal, F., Gallouj, F., 2000. Innovation surveys for service industries: a review. In: Paper Presented at the DG Enterprise Conference on Innovation and Enterprise Creation: Statistics and Indicators, Sophia Antipolis, France, November 2000.

Drejer, I., 2004. Identifying innovation in surveys of services: a Schumpeterian perspective. Research Policy 33, 551-562.

Furunes, T., 2005. Training paradox in the hotel industry. Scandinavian Journal of Hospitality \& Tourism 5 (3), 231-248.

Galende, J., 2006. Analysis of technological innovation from business economics and management. Technovation $26,300-311$.

Gallouj, F., Weinstein, O., 1997. Innovation in services. Research Policy 26, 537-556. Gavious, A., Rabinowitz, G., 2003. Optimal knowledge outsourcing model. Omega 31, 451-457.

Getz, D., Carlsen, J., 2005. Family business in tourism. State of the art. Annals of Tourism Research 32, 237-258.

Guerrier, Y., Deery, M., 1998. Research in hospitality human resource management and organizational behavior. Hospitality Management 17, 145-160.

Heine, M., Grover, V., Malhotra, M., 2003. The relationship between technology and performance: a meta-analysis of technology models. Omega 31, 189-204.

Hjalager, A., 2002. Repairing innovation defectiveness in tourism. Tourism Management $23,465-474$.

Instituto de Estudios Turísticos, 2003. Evolución del turismo en España año 2002. Ministerio de Comercio y Turismo, Secretaría General de Turismo, Madrid.

Landau, R., 1991. How competitiveness can be achieved: fostering economic growth and productivity. In: Landau, R. (Ed.), Technology and Economics: Papers Commemorating Ralph Landau's Service to the National Academy of Engineering. National Academy Press, Washington, DC, pp. 3-46.

Leiponen, A., 2005. Skills and innovation. International Journal of Industrial Organization 23, 303-323.

Lopez-Cabrales, A., Valle, R., Herrero, I., 2006. The contribution of core employees to organizational capabilities and efficiency. Human Resource Management 45 (19), 81-109.

Lynch, P., MacWhannell, D., 2000. Home and commercialised hospitality. In: Lashley, C., Morrison, A. (Eds.), In Search of Hospitality: Theoretical Perspectives and Debates. Butterworth-Heinemann, Oxford, pp. 100-117.

Ngai, E., Wat, F., 2003. Design and development of a fuzzy expert system for hotel selection. Omega 31, 275-286.

Pine, R., 1992. Technology transfer in the hotel industry. International Journal of Hospitality Management 11, 3-22.
Pfeffer, J., 1998. The Human Equation: Building Profits by Putting People First. Harvard Business School Press, Boston.

Preissl, B., 2000. Service innovation: what makes it different? Empirical evidence from Germany in innovations systems. In: Metcalfe, J.S., Miles, I. (Eds.), The Service Economy. Kluwer Academic Publishers, Boston.

Poon, A., 1993. Tourism, Technology and Competitive Strategies. CAB International, Wallingford.

Ramos, V., Rey-Maquieira, J., Tugores, M., 2004. The role of training in changing an economy specialising in tourism. International Journal of Manpower 25, 55-72. Saks, A.M., Belcourt, M., 2006. An investigation of training activities and transfer of training in organizations. Human Resource Management 45 (4), 629-648.

Schneider, B., Bowen, D., 1985. Employee and customer perceptions of service in banks: replication and extension. Journal of Applied Psychology 70, 423-433.

Schneider, B., Parkington, J., Buxton, V., 1980. Employee and customer perceptions of service in banks. Administrative Sciences Quarterly 25, 252-267.

Schneider, B., White, S., Paul, M., 1998. Linking service climate and customer perception of service quality in banks: test of a causal model. Journal of Applied Psychology 87, 220-229.

Schumpeter, J., 1942. Capitalism, Socialism and Democracy. Harper and Brothers, New York.

Sirilli, G. Evangelista, R. 1998. Technological innovation in services and manufacturing: results from Italian surveys. Research Policy 27, 881-899.

Sundbo, J., 1997. Management of innovation in services. Service Industries Journal $17,432-455$

Sundbo, J., 2000. Organization and innovation strategy in services. In: Boden, M. Miles, I. (Eds.), Services and the Knowledge-Based Economy. Continuum, London, pp. 109-128.

Sundbo, J., Gallouj, F., 2000. Innovation as a loosely coupled system in services. International Journal of Service Technologies and Management 1,15-36.

Tremblay, P., 1998. The economic organization of tourism. Annals of Tourism Research 25, 837-859.

Tsaur, S., Lin, Y., 2004. Promoting service quality in tourist hotels: the role of HRM practices and service behavior. Tourism Management 25, 471-481.

Wiley, J., 1996. Linking survey results to customer satisfaction and business performance. In: Kraut, A. (Ed.), Organizational Surveys: Tools for Assessment and Change. Jossey-Bass, San Francisco.

Winata, L., Mia, L., 2005. Information technology and the performance effect of manager's participation in budgeting: evidence from the hotel industry. Hospitality Management 24, 21-39.

Wong, S., Pang, L., 2003. Motivators to creativity in the hotel industry-perspectives of managers and supervisors. Tourism Management 24, 551-559.

Yeung, A., 2006. Setting people up for success: how the Portman Ritzcarlton Hotel gets the best from its people. Human Resource Management 45 (2), 267-275.

Zaccaro, S.J., Banks, D., 2004. Leader visioning and adaptability: bridging the gap between research and practice on developing the ability to manage change. Human Resource Management 43 (4), 367-380. 